University of Nebraska - Lincoln

DigitalCommons@University of Nebraska - Lincoln

Faculty Publications from the Harold W. Manter Laboratory of Parasitology

7-1958

The Occurrence and Distribution of Birds on Middleton Island, Alaska

Robert L. Rausch

University of Washington, rausch@uw.edu

Follow this and additional works at: https://digitalcommons.unl.edu/parasitologyfacpubs

Part of the Parasitology Commons

Rausch, Robert L., "The Occurrence and Distribution of Birds on Middleton Island, Alaska" (1958). Faculty Publications from the Harold W. Manter Laboratory of Parasitology. 376.

https://digitalcommons.unl.edu/parasitologyfacpubs/376

This Article is brought to you for free and open access by the Parasitology, Harold W. Manter Laboratory of at DigitalCommons@University of Nebraska - Lincoln. It has been accepted for inclusion in Faculty Publications from the Harold W. Manter Laboratory of Parasitology by an authorized administrator of DigitalCommons@University of Nebraska - Lincoln. 


\section{THE OCCURRENCE AND DISTRIBUTION OF BIRDS ON MIDDLETON ISLAND, ALASKA}

\section{By ROBERT RAUSCH}

The Prince William Sound region of southern Alaska lies just east of the Kenai Peninsula, and not far from the northwestern limits of the coastal forest zone. Although the avian fauna of this general region is relatively well known, previous studies have not included Middleton Island, which lies in the Gulf of Alaska well to the south of the many islands comprising the archipelago of Prince William Sound (fig. 1). Because of its location, small size, topography, and its vegetational and faunal characteristics, Middleton Island would appear to be of considerable ornithological interest. Also, because of current military activities on this island, the imminent disruption of its natural relationships make it desirable to record as much as possible of its natural history before the opportunity is lost.

In June, 1956, a field party consisting of Dr. Norman J. Wilimovsky, United States Fish and Wildlife Service, Dr. John H. Thomas, Stanford University, and the writer undertook a biological reconnaissance of Middleton Island. The work was supported mainly by the Office of Naval Research and the United States Air Force, but additional support was provided by the Arctic Research Laboratory, Stanford University, and the Arctic Health Research Center. These studies were aided by a contract between the Office of Naval Research, Department of the Navy, and the Arctic Institute of North America. Reproduction in whole or in part is permitted for any purpose by the United States Government.

Over a period of 15 days in the field (June 5 to 15 and June 25 to 28 ), the writer recorded the species of birds observed and attempted to define the ecological distribution of the breeding species. Insofar as possible, the distribution of the latter was correlated with well-defined plant communities and associated topographic features.

The subspecific determinations of the birds collected were made by Dr. Alden $\mathrm{H}$. Miller and Dr. Frank A. Pitelka, University of California, and by Dr. Herbert Friedmann, United States National Museum. The only specimens collected previously on Middleton Island appear to be those taken by $\mathrm{C}$. H. Townsend, who visited the island briefly in August, 1888. These birds, now in the United States National Museum, have been listed by Ridgway (1893).

\section{GENERAL GEOGRAPHIC AND BIOLOGICAL CHARACTERISTICS OF MIDDLETON ISLAND}

Topography.-Middleton Island is approximately five miles long, with a maximum width not exceeding one mile. It lies about 50 miles southeast of Montague Island and 70 miles south of the nearest point on the Alaskan mainland (fig. 1). Its geology and geography have been reviewed recently by Miller (1953:18-21), who described the more prominent topographic features as follows:

"The most striking feature of the island is the steplike character of its surface, which consists of a series of terraces at average altitudes of $10,45,65,85$, and 105 feet. Conical to ellipsoidal mounds, as much as 20 feet high and grouped in several rows, rise above the general level of the highest terrace to a maximum altitude of 126 feet. The 10-foot and 45-foot terraces slope off gradually near the north end of the island, merging into the present beach and an area of irregular sand dunes. A low spit of sand and gravel forms the north end of the island.

"Steep sea cliffs, undergoing rapid erosion, form the high-tide shore line around much of the island. Along the east and southeast shore the present sea cliff ranges in height from 10 to 45 feet (pl. 2, A). Along the south shore and southern part of the northwest shore it rises in steps to a maximum height of about 110 feet as it intersects, successively, the 65-, 85-, and 105-foot terraces. Most 


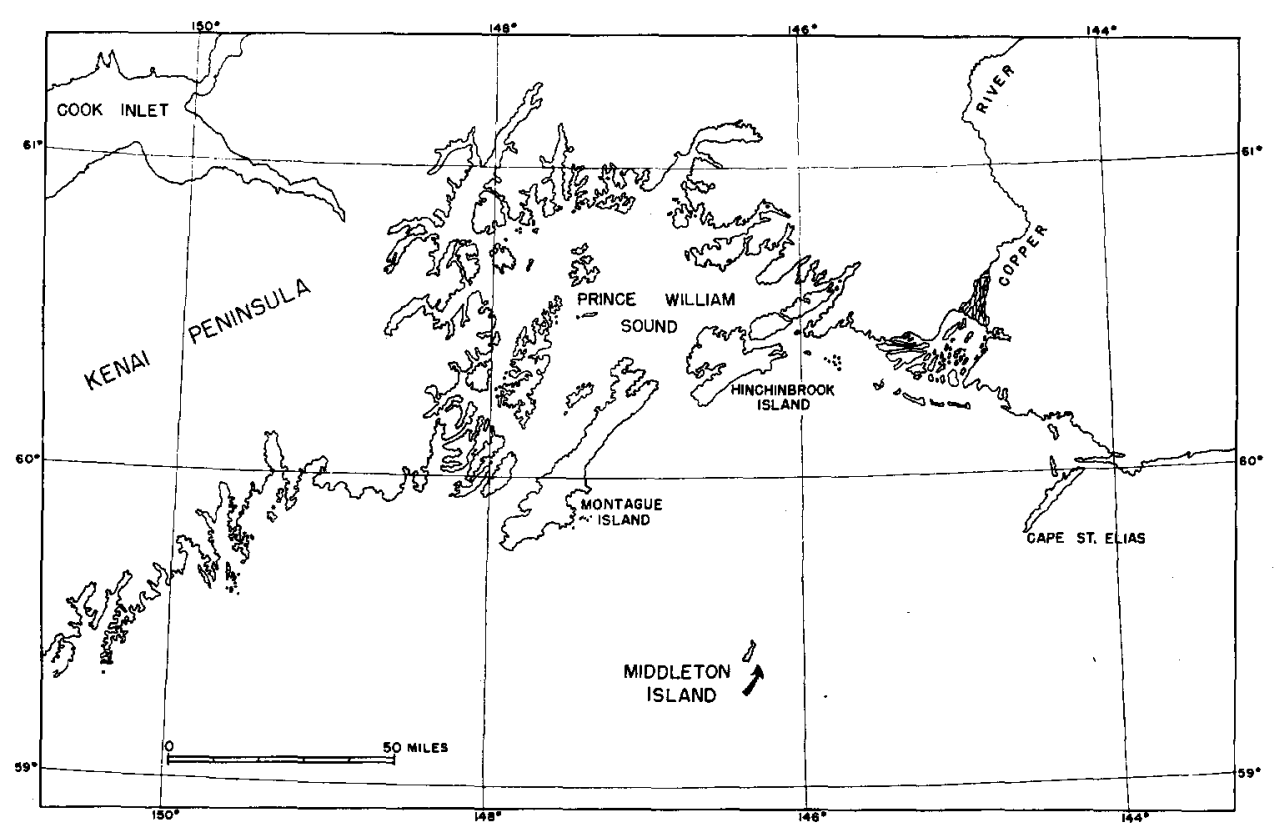

Fig. 1. Map of Prince William Sound region showing the location of Middleton Island.

of the northern part of the northwest shore is flanked by a low cliff at the margin of the 10-foot terrace."

Along the western side of the island are sandy beaches and beach ridges, with a considerable quantity of driftwood. Adjacent to the beach ridges, and extending inland to the base of a steep, west-facing bluff, is a broad, marshy area with several ponds. Most of these ponds are temporary, drying up rapidly after the wet period of early spring. The largest of these ponds, situated near the beach ridge along the northwest end of the island, is temporary and brackish, having a salinity of $388.3 \mathrm{mg} . / 1$ in June, 1956. The ponds had a rich plankton, but they contained no fishes. Within this marshy area, there were a number of low mounds. Several small drainages were present along the bluff which bordered the east side of the marsh. A few small drainages were found also on the higher terraces near the south end of the island; one of these dropped rapidly into the sea through a bed of moss-covered boulders. Several large boulders, most of which supported dense vegetation, were scattered about on the high ground at the south end of the island. In this area also, there were occasional small ponds or marshy areas.

Climate.-Middleton Island has a maritime climate with rather moderate temperatures. The average annual temperature for 1956 was $40.3^{\circ} \mathrm{F}$; the average for the warmest month (August) was $53.3^{\circ} \mathrm{F}$. and for the coldest (February) $-5^{\circ} \mathrm{F}$. The total precipitation for 1956 was 51.18 inches, with a departure of -10.3 inches from the longterm mean. High winds are common, especially during the colder months. During the winter, the wind blows mainly from the north and east; during the summer, the prevailing wind is from the southwest.

Mammals.-Fur farming was undertaken on Middleton Island in about 1895, with the introduction of arctic foxes (Alopex lagopus) brought originally from the Pribilof Islands. According to Mr. Martin Caping, now employed by the Arctic Health Research Center, who spent the winter of 1921 on Middleton Island, there were from 200 to 300 
foxes on the island during the 1920's. Although supplemental feed was provided, particularly in the winter months, the foxes subsisted to a large extent upon birds and other natural food during the spring and summer. Eventually, when fur prices dropped, fur farming was discontinued. As far as can be determined, there have been no foxes on Middleton Island for the last 15 to 20 years.

The extent to which the foxes affected the indigenous fauna of the island cannot now be assessed. The writer found no evidence of any indigenous terrestrial mammals. Detailed examination of the most favorable habitat disclosed no old runways, fecal pellets, nests, or other signs of small mammals. Extensive trapping in selected habitats likewise gave negative results. A few pellets from predatory birds were found around the boulders at the south end of the island, and these contained only avian remains. In discussing the mammalian fauna of the Prince William Sound region, Heller (1910) stated, "It is now quite impossible to determine what species of mammals occurred on the islands that have been used as fox farms for any considerable time." He obtained good evidence that both microtine rodents and shrews had been eliminated from certain islands by foxes. The same thing might have happened on Middleton Island.

In the fall of 1952 , domesticated rabbits were introduced by communications personnel stationed on Middleton Island. These animals were fed during the first winter, but they became well established and self-sufficient. In the spring of 1956, they were estimated to exceed 200 in number. At that time, the rabbits were found mainly around the north end of the island, but they will do doubt become more widely distributed if they continue to increase in numbers. Some local damage to the vegetation was noted. According to information provided by Dr. Robert F. Scott, United States Fish and Wildlife Service, 8 to 10 Snowy Owls (Nyctea scandiaca) invaded the island in late November, 1957. These birds appeared to be feeding exclusively upon the rabbits, and, if they are not destroyed, they may serve effectively to reduce the rabbit population.

\section{VEGETATION AND DEFINITION OF ECOLOGICAL FORMATIONS}

Since the vascular plants of Middleton Island have been studied by Thomas (1957), this discussion is limited mainly to the communities selected in connection with the distribution of the breeding birds. The names of the plants included here are according to the annotated list published by Thomas.

The vegetation is generally low and composed of herbaceous plants. Shrubby willows (Salix barclayi) occur over much of the marshy area along the west side of the island, and a few scattered stands are found in the wet areas at higher elevations. A narrow zone made up mainly of large willows borders the steep bluff adjacent to the marshy area along the west side of the island. Spruce trees (Picea sitchensis) have become established, but they are widely scattered and would seem to have little importance in connection with the present work. The beach ridge is grown to plants characteristic of this habitat. Over the remainder of the island the vegetation is relatively uniform, except where local variations occur as a result of the effect of moisture and other factors.

For the purpose of the present study, the writer has recognized six major ecological formations. All but one of these are characterized by their vegetation, and their distribution on the island is shown in figure 2 . Profiles of the island, showing all six formations, are portrayed in figure 3 (see fig. 2 for location of profiles). The general characteristics of the formations are described briefly as follows:

I. Upper beach and beach ridge.-At the north tip of the island was a relatively small area of sand dunes. From here, a well-defined, sandy beach ridge extended along the west side of the island about half-way to the south end. Farther to the south, the beach ridge became less evident, and it finally disappeared, being replaced by a low cut-bank which extended south until it terminated against 
Rausch in the Condor (July 1958) 60. Copyright 1958, Cooper Ornithological Society. Used by permission.

\section{EXPLANATION}

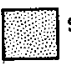

SANDY OR ROCKY BEACH
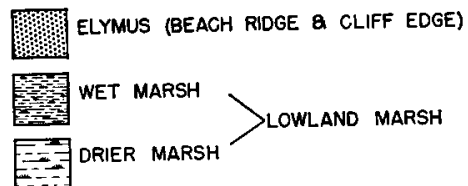

HIGH-SHRUB ZONE

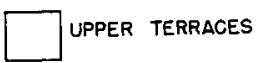

DENSER VEGETATION OF
GLIFF AND BANK EDGES

---- MARGINS OF TERRACES

- EXTENT OF ROCKY GLIFF

* * MOUNDS ON HIGHEST TERRACE

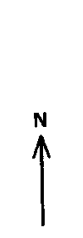

$* *$ MOUNOS ON HIG

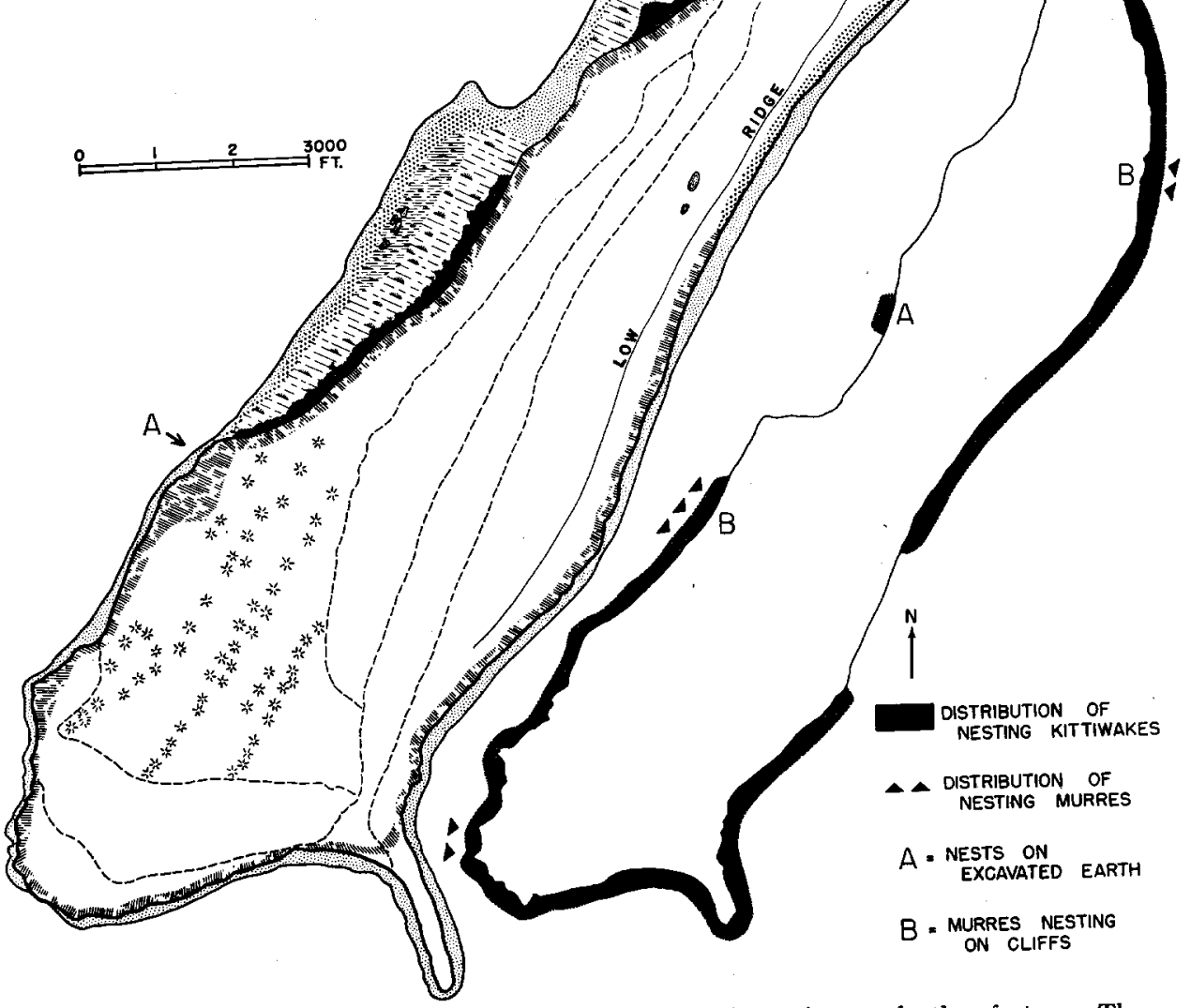

Fig. 2. Left, map of Middleton Island showing ecologic formations and other features. The letters " $A$ " and " $B$ " indicate the points at which the profiles shown in figure 3 were drawn; right, map of Middleton Island showing distribution of nesting kittiwakes and murres. 
a steep cliff. Seaward, the beach was sandy or composed of either exposed bedrock or boulders. The upper beach, however, was sandy throughout on the west side, although there were scattered boulders. The predominant plant was Elymus arenarius ssp. mollis, which grew also along the aforementioned cut-bank. Other important plants here were Senecio pseudo-arnica, Lathyrus japonicus, Arenaria peploides, Angelica lucida, and Fragaria chiloensis. Mertensia maritima was common along the upper beach. A considerable amount of driftwood had been deposited along the beach ridge and beyond, so that much of it was concealed in the dense growth of Elymus.
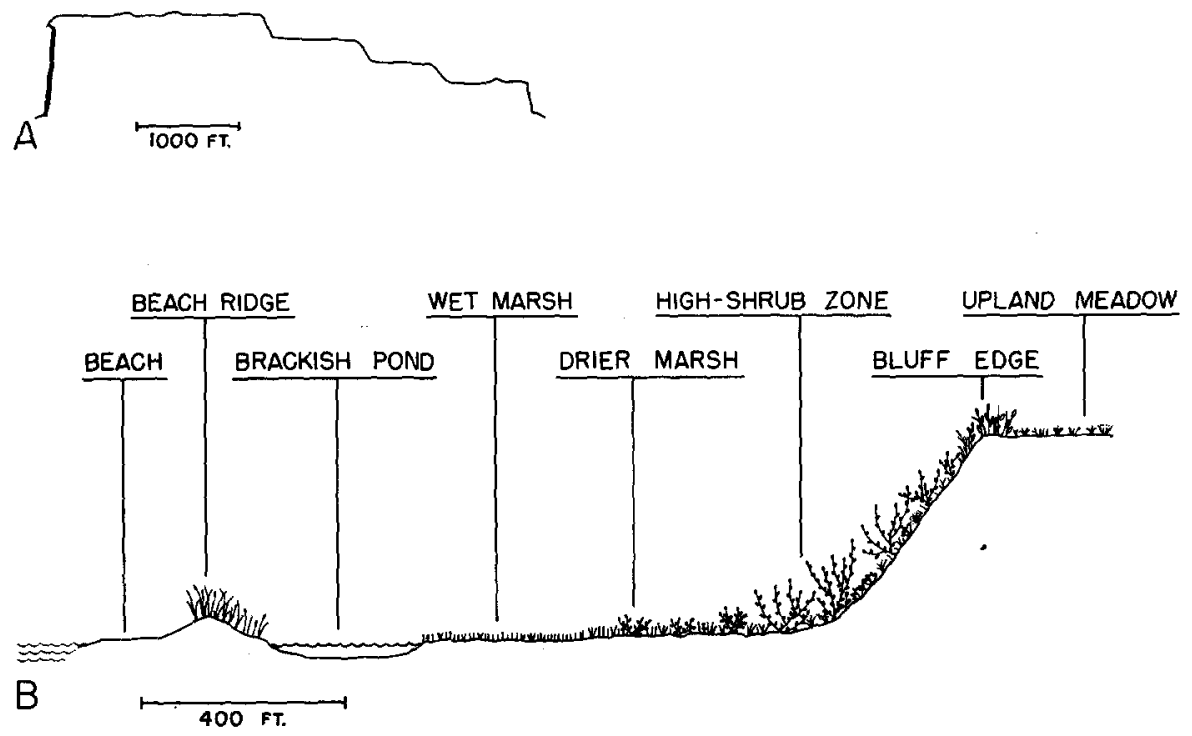

Fig. 3. Profiles of Middleton Island. "A" represents a cross-section of the island, as indicated in figure 2; " $\mathrm{B}$," also indicated in figure 2, depicts four of the major ecologic formations. Vertical scales are much exaggerated.

II. Lowland marsh.-The west side of the island was bordered by a rather extensive marshy zone, which was bounded to the east by a steep bluff. It corresponded in area to the lowest of the terraces. Scattered ponds, nearly all situated just inland from the beach ridge, were found here. The aquatic vegetation of the freshwater ponds consisted predominantly of Potamogeton filiformis and Hippuris tetraphylla. These ponds were surrounded by Carex lyngbyei ssp. cryptocarpa, Polygonum sp., Potentilla egedii var. groenlandica, and $\boldsymbol{P}$. palustris. The brackish ponds were surrounded mainly by $\boldsymbol{J}$ uncus sp.,Carex lyngbyei ssp. cryptocarpa, and Polygonum amphibium. Inland from the ponds, the wetter areas supported a dense growth comprised largely of Sphagnum sp., Equisetum variegatum, Carex pluriflora, Habenaria sp., Caltha palustris ssp. asarifolia, Empetrum nigrum, and Menyanthes trifoliata. Lysichiton americanum was locally abundant, particularly along small drainages. East of the ponds near the northwest end of the island were a few low mounds. These were well drained and supported a vegetation essentially like that found on the higher terraces. Small stands of Salix barclayi were found here. The eastern part of this area (see fig. 4) was somewhat drier and, in addition to many of the plants listed above, low willows were numerous.

III. High-shrub zone.--The base and sides of the bluff bordering the east side of the marsh supported a dense growth of vegetation, in which Salix barclayi attained a maximum height of about 10 feet (fig. 4). This bluff originated near the north end of the island, and it increased gradually in height until it terminated against the sea cliff running along the southwest shore. In general, the willows formed a rather dense canopy, and the undergrowth consisted mainly of Rubus spectabilis, Dryopteris austriaca, and, in wet areas, Lysichiton americanum. In some places, Rubus spectabilis formed dense stands. Also present were Sambucus racemosa ssp. pubens; Urtica lyalli, Angelica lucida, and Heracleum maximum, among others. 

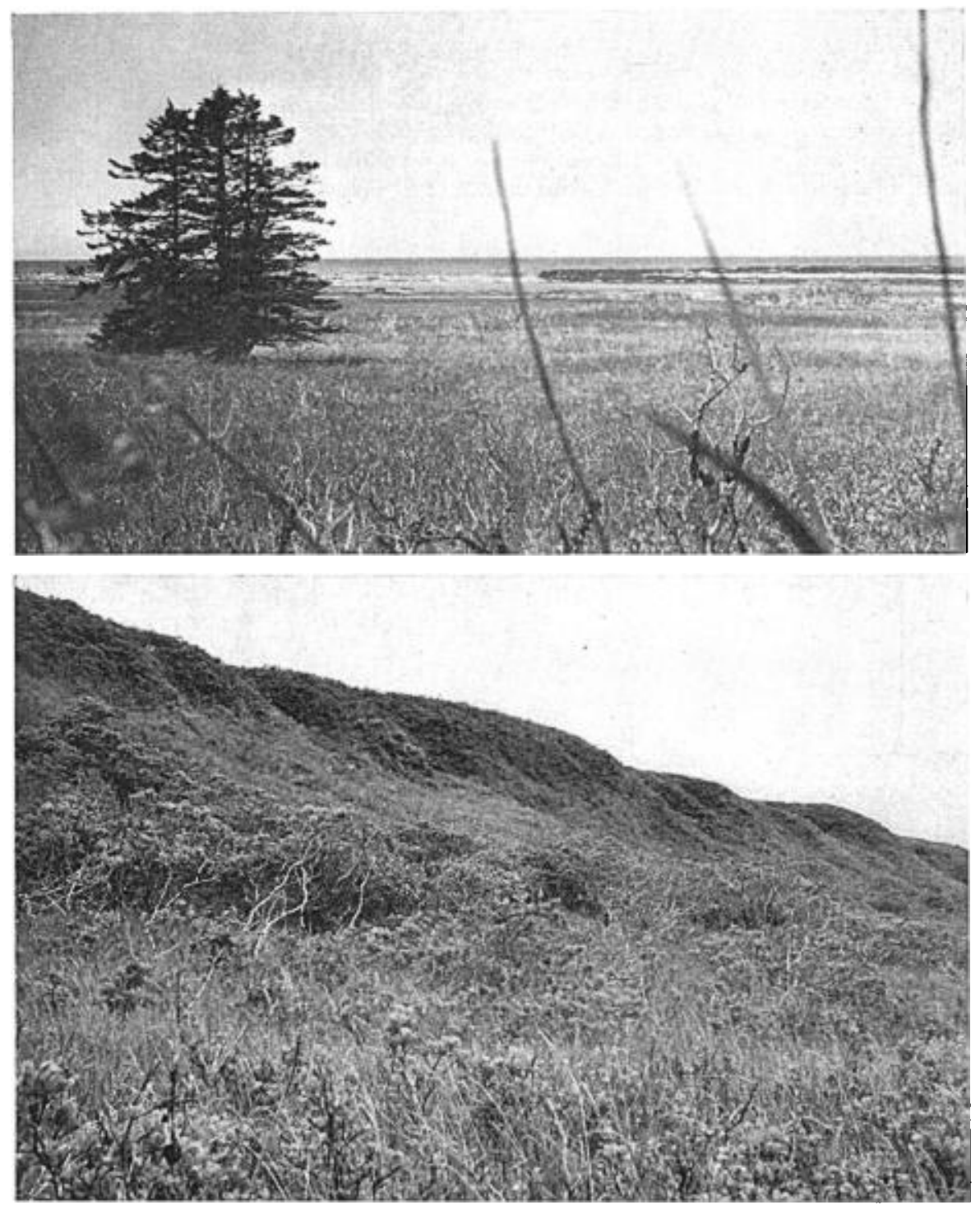

Fig. 4. Above: view westward from drier marsh to largest pond and beach ridge; isolated spruce in foreground.

Below: view southward along base of bluff; high-shrub zone is sparse here.

IV. Upland meadow.-The two highest terraces supported a relatively uniform growth of vegetation (fig. 5); the following plants were abundant: Calamagrostis nutkaensis, Maianthemum dilatatum, Anemone narcissiflora ssp. alaskana, Ranunculus occidentalis var. brevistylis, Geranium erianthum, Angelica lucida, Dodecatheon pulchellum, and Plantago macrocarpa. One rather extensive marshy area near the center of the island supported a dense growth of Eriophorum russeolum and Carex $\mathrm{sp.}$ A few small drainages near the south end of the island were bordered by Caltha palustris ssp. asarifolia, Lysichiton americanum, and Carex sitchensis. There were.also a few low stands of Salix barclayi. The east-facing banks of the terrace margins were grown to most of the species found on the higher 


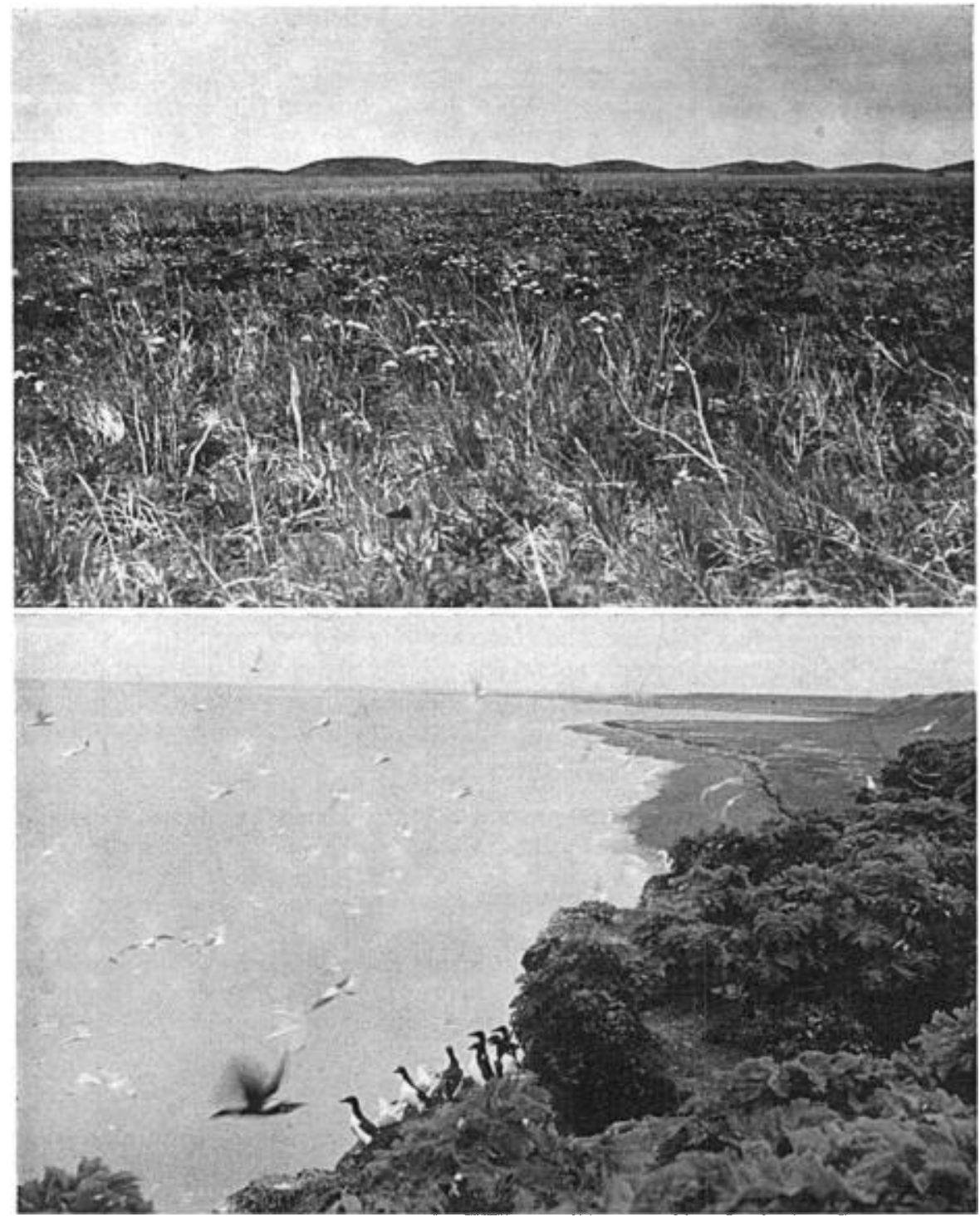

Fig. 5. Above: view across highest terrace, with mounds in background. Below: top of cliff grown to umbellifers; southern portion of marsh and bluff in background.

terraces, but in addition they supported Viola sp., Rubus stellatus, Cornus suecica, Fritillaria camschatcensis, Castilleja unalaschcensis, and Epilobium angustifolium, among others. The mounds on the highest terrace supported vegetation similar to that of the terrace margins. The lower terrace running along the east side of the island supported a variety of plants. A low ridge paralleling the shore but a short distance inland was grown to vegetation typical of the better-drained situations; common here were Angelica lucida, Calamagrostis sp., Plantago macrocarpa, Geranium erianthum, Dodecatheon pulchellum, and some Elymus arenarius ssp. mollis. Adjacent to this ridge was a long marshy zone, grown mainly to Carex sp. Small ponds here supported Hippuris tetraphylla and Menyanthes trifoliata. 
Nuphar polysepalum occurred in one pond. There was a rather extensive marshy area at the south end of the island, at the lowest level.

V. Cliff edge.-Although its composition was by no means uniform, the vegetation of the cliff edges was chiefly characterized by unusual height and density. This relatively narrow zone was especially well defined along the west side of the island, where it bordered the edge of the bluff and, farther south, the sea cliffs. Here, Rubus spectabilis was often predominant, but also present were Epilobium angustifolium, Calamagrostis sp., Geum macrophyllum, Angelica lucida, and Heracleum maximum, among others. In some places, where birds were especially abundant, the umbellifers were predominant (fig. 5), and it appeared that fertilization by the feces of birds had affected the vegetation of the cliff edges. On the east side of the island, this zone was not nearly so well defined, and it differed little from the adjacent vegetation. On the east side, from about mid-way up the island, the cliff edge was bordered by a rather sparse stand of Elymus sp.

VI. Rocky cliff.-Much of the island is bounded by perpendicular cliffs of varying height. Along the southwest and south end of the island, these are devoid of vegetation. In a few places, slides of earth dislodged by erosion have fallen upon sloping faces and have remained. These usually supported some vegetation. Along the east side, the cliffs were lower, and their structure differed from place to place, there being some areas with a gradual slope as well as perpendicular cliffs of rock. Around the north end, the cliffs were higher and quite precipitous.

\section{THE AVIAN FAUNA}

Forty-five species of birds were recorded. Of these, at least 16 were breeding on the island, four were possibly breeding, and the remaining 25 were regarded as transients. For convenience, the breeding and nonbreeding birds are considered separately. The breeding birds are listed according to the major ecologic formations in which they occurred. All names are according to the American Ornithologists' Union (1957).

\section{BREEDING BIRDS}

I. UPPER BEACH AND BEACH RIDGE.-Charadrius semipalmatus. Semipalmated Plover. This bird was the only species found breeding on the beach ridge, where it was common. It was not observed elsewhere. The plovers regularly showed decoy behavior on June 5 , the earliest date on which observations were made. A female collected on June 7 had ova up to $18 \mathrm{~mm}$. in diameter.

Troglodytes troglodytes. Winter Wren. See under Formation III.

II. LOWLANd MARSh.-Anas acuta. Pintail. Pintails were frequently observed on the largest pond. Males accompanied by females were seen on June 6 and 10. On June 11, a female and several downy young were flushed a short distance inland from the ponds. On this day also, Dr. John Thomas observed another female with young. None was collected.

Anas carolinensis. Green-winged Teal. A pair of these ducks was observed on the largest pond on June 6. Three adults, including a male, were seen on smaller ponds on June 10, and single birds were noticed from time to time. Although no nests were found, the ducks apparently were nesting in the vicinity of the low mounds just east of the largest pond. None was collected.

Lobipes lobatus. Northern Phalarope. This was a common shorebird, seen daily in favorable habitat. A pair was observed copulating in the water on June 10. Two nests, each containing four eggs, were found on June 12; these were located in dry vegetation not far from the ponds in an area grown mainly to Carex sp. and Potentilla sp. A female collected on June 25 weighed 31.4 grams; the brood patch had largely refeathered, and molt was beginning.

Capella gallinago delicata. Common Snipe. This bird was seen occasionally in favorable habitat, and its winnowing was heard often in early June. A male, with testis measuring $13 \mathrm{~mm}$., was collected on June 6. No nests were found.

Erolia minutilla. Least Sandpiper. The most abundant shorebird on the island, the Least Sandpiper was seen daily in the drier parts of the-marsh. A female_collected on June 6 had ova up to 2 $\mathrm{mm}$. in diameter; two males collected on June 7 had testes measuring 3 and $7 \mathrm{~mm}$. long, respectively. Although the behavior of these birds clearly indicated that they were breeding, no nests were found.

Passerculus sandwichensis anthinus. Savannah Sparrow. See under Formation IV.

III. HIGH-SHRUB zoNE.-Troglodytes troglodytes. Winter Wren. The Winter Wren was common 
throughout this formation, in which it attained its maximum abundance. The males frequently sang from the tall stalks of Rubus spectabilis or from dead willow branches. Because of the density of the vegetation, they were not easily observed. No nests were found. Of the several females collected, all showed well-developed brood patches. Along the beach ridge (Formation I), a few wrens were found nesting in driftwood which was concealed in Elymus opposite the largest pond. Two birds were collected here on June 25 ; a male weighed 10 grams, with testis $7 \times 4 \mathrm{~mm}$., and a female weighed 9.2 grams, with follicles up to $1 \mathrm{~mm}$. in diameter. In Formation V, these birds were frequently seen along the west side of the island, where the males sometimes sang from the stalks of Rubus spectabilis. The wrens were rarely seen along the south end and east side of the island, where the composition of the vegetation was much different.

Dendroica petechia rubiginosa. Yellow Warbler. This was one of the characteristic birds of the shrub formation. It was abundant, and the males were often observed singing from dead willow twigs. They also sang in the shrubby willows adjacent to this formation. Nine specimens were collected, of which six were males. All were in breeding condition. C. H. Townsend collected three specimens on Middleton Island in 1888.

Acanthis flammea. Common Redpoll. Although uncommon, the redpoll may have nested on the island. One was observed in flight on June 6 . On June 11, a male in full breeding plumage responded to "squeaking" and perched within a few feet of the writer, too close to permit its being shot. The high-shrub zone closely resembled the typical breeding habitat of the redpoll.

Passerella iliaca sinuosa. Fox Sparrow. Next to the Savannah Sparrow, the Fox Sparrow was the most numerous passeriform bird on the island. It was closely restricted to the zone of high shrubs and its borders. Although generally shy, the birds often could be called in. The males sang from the tops of the higher willows, or from the high stalks of Rubus spectabilis along the upper bluff. Ten specimens were collected. A female shot on June 9 contained a fully-developed egg in the lower oviduct. Fox Sparrows were often observed in Formation V, particularly along the edge of the bluff where the vegetation was contiguous with the dense growth on the side of the bluff. Farther south, near the beginning of the sea cliff, Fox Sparrows were common in a relatively wide zone of vegetation. Foraging and singing were observed here, but there was no evidence of nesting. Two of these birds were collected on Middleton Island by Townsend in 1888; the specimens were later studied by Grinnell (1910).

Spizella arborea ochracea. Tree Sparrow. On June 28, two male Tree Sparrows were collected along the west edge of the high-shrub zone, opposite the largest pond. One bird weighed 18.5 grams and the other 18.9 grams; in both, the testes measured $7 \times 4 \mathrm{~mm}$. This species may breed on Middleton Island, but it was uncommon at the time of these observations.

IV. UPLAND MEADOw.-Passerculus sandwichensis anthinus. Savannah Sparrow. Savannah Sparrows were most numerous on the drier, upper terraces, particularly on the highest terrace where Calamagrostis nutkaensis was abundant. A nest containing five eggs was found on June 5. On June 25 , the birds were feeding young, most of which had fledged. Some of the adult birds collected at this time were carrying tipulids of large size, and caddisflies (Lenarchus vastus). Fully feathered young were collected on June 25 and 26. Savannah Sparrows were also quite numerous in Formation II, especially among the shrubby willows along the east side of the marsh. A nest found here on June 11 contained heavily incubated eggs. Twenty-one specimens were collected. Three were collected in 1888 by C. H. Townsend. The Savannah Sparrows of Middleton Island are a thick-billed form. According to Dr. Herbert Friedmann (personal communication), they would be referable to the southern Alaskan race crassus, currently considered a synonym of anthinus.

Calcarius lapponicus alascensis. Lapland Longspur. A few pairs of longspurs were observed on the highest terrace, where they were nesting. Two males were collected on June 9; both were in breeding condition, one with testis $12 \mathrm{~mm}$. in length. An adult female was collected on June 26 in a bird-net placed in the willows along the bluff. One pair was seen among driftwood along the beach ridge just west of the largest pond; the birds apparently were nesting.

V. CLIFF TOP.-Rissa tridactyla pollicaris. Black-legged Kittiwake. See under Formation VI.

Uria aalge and Uria lomvia arra. Common Murre and Thick-billed Murre. See under Formation VI.

Lunda cirrhata. Tufted Puffin. On Middleton Island, the nest burrows of the Tufted Puffin were 

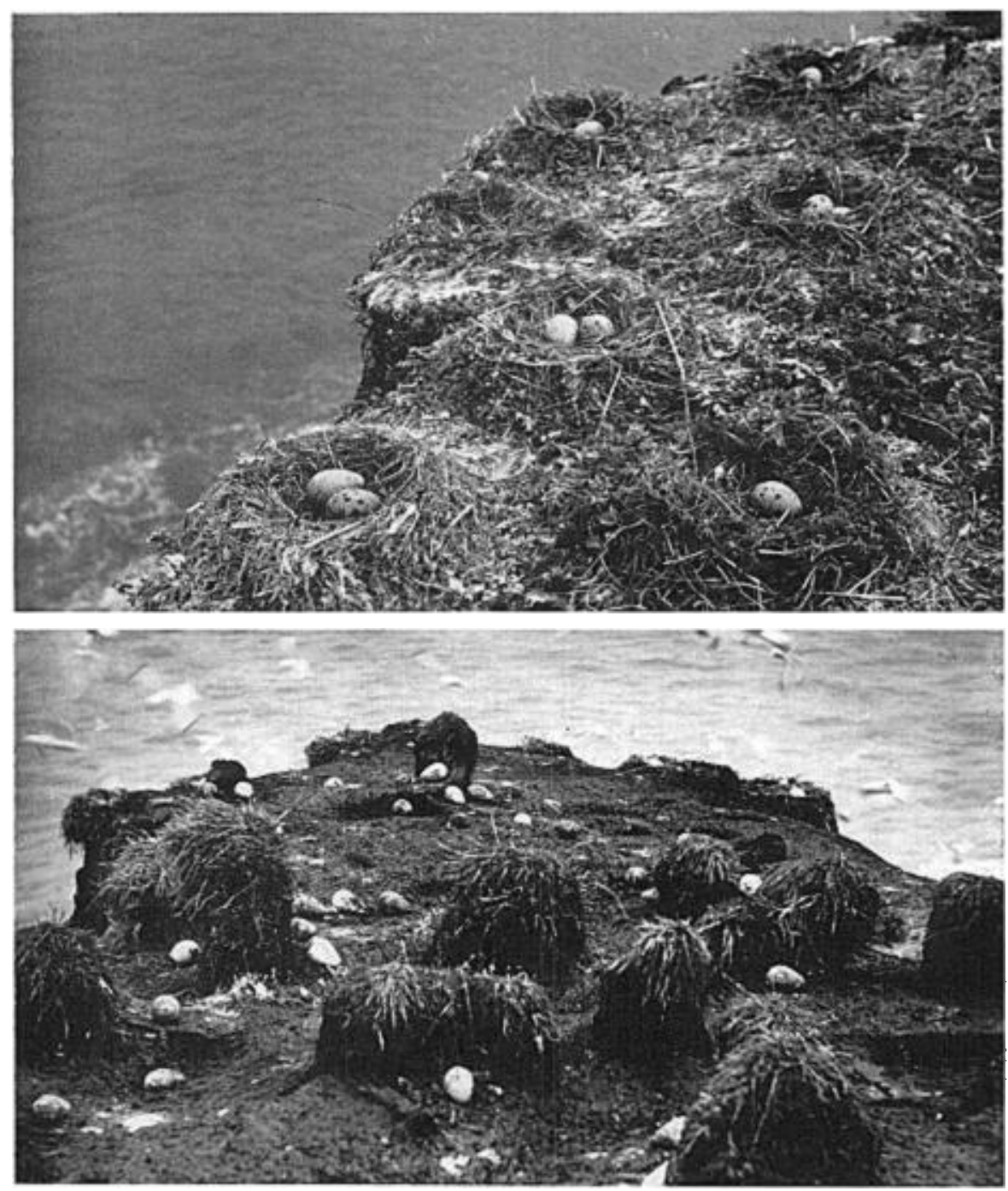

Fig. 6. Above: kittiwake nests along top of cliff.

Below: murre eggs among old tussocks of Calamagrostis along top of cliff.

most commonly found in the black humus along the top of the cliffs. They were usually excavated where vegetation was sparse or lacking, but some were observed in areas supporting rather large stands of umbellifers. Only a few burrows contained eggs on June 5. An egg examined on June 9 contained a small embryo. These birds were most numerous along the southwest and south ends of the island, but a few were found along the southeast side as well. Tufted Puffins were found infrequently along the cliff sides (Formation VI) since the perpendicular cliffs provided no place for nest burrows. In a few locations, however, the puffins had constructed burrows in masses of soil which had fallen from above onto more sloping cliffs. At the south end of the bluff, where the latter terminated against the cliffs on the southwest side of the island, a long slope was much used by these birds. One Tufted Puffin was collected here in 1888 by C. H. Townsend.

Troglodytes troglodytes. Winter Wren. See under Formation III.

Passerella iliaca sintwosa. Fox Sparrow. See under Formation III. 
VI. ROCKY CLIFF.-Phalacrocorax pelagicus. Pelagic Cormorant. This was the second most abundant species of cliff-nesting birds. The cormorants were restricted in their nesting distribution mainly to the lower west side and south side of the island, where they occurred in association with kittiwakes and, in one area, with murres. Two subadult birds, conspicuous by their brown color, were observed at the south end of the island. These birds were very shy and were seen only on June 5 and 9 . The nests of the cormorants were usually located well up the sides of the cliffs, often just below the top. The nests were frequently placed upon soil in places where erosion of the cliff edges had provided narrow ledges. Most of the nests contained three eggs on June 5, although a few contained four. The first newly-hatched young were seen on June 10 . By June 25 , nearly all eggs had hatched, but the young birds differed greatly in age. No specimens were collected.

Rissa tridactyla pollicaris. Black-legged Kittiwake. The kittiwake was by far the most abundant bird on the island. All available nesting sites from the top of the cliffs to within a few feet above the high tide line appeared to be occupied. The distribution of the nesting kittiwakes is shown in figure 2 . At one location on the west side of the island, kittiwakes were nesting on a slope of relatively loose soil which had been pushed over the bluff by a bulldozer within the last two years. On June 5, the nests contained from one to three eggs, the majority having two. Only about half the nests contained young by June 25 . Birds in immature plumage were uncommon; perhaps 10 were seen around the south end of the island. One of these was collected. Near the south end of the island, kittiwakes nested commonly along the top of the cliff (Formation V), where vegetation was sparse or lacking. The total number of nests was not determined, but there were more than 100 nests on level ground (fig. 6). In other places, where the cliff edges had eroded, earth ledges just below the top of the cliff also were utilized. In general, nests in such locations were adjacent to the nests of birds on the cliffs below. Two kittiwakes were collected on Middleton Island in 1888, by C. H. Townsend.

Uria aalge and Uria lomvia arra. Common Murre and Thick-billed Murre. Murres were found nesting on the cliff sides in but two localities (fig. 2). They were more numerous on the upper cliff bordering the west side of the island, just south of the junction of this cliff and the bluff. On the east side of the island, about six pairs of murres were seen. The eggs were placed on eroded soil just under the cliff top; they were not seen on rock ledges. Thick-billed Murres were several times more abundant than the Common Murres. The nesting success of the murres appeared to be very low, many of the eggs having been destroyed by gulls. The largest aggregation of murres, numbering about 200 , was found at the south end of the island. They were nesting here on the level ground at the top of the cliff. With the exception of a few old tussocks of Calamagrostis nutkaensis, the vegetation had apparently been destroyed by the activity of the birds. The eggs had been deposited on rather wet soil around the tussocks (fig. 6). A few eggs examined on June 9 had not yet begun to embryonate.

Lunda cirrhata. Tufted Puffin. See under Formation V.

In addition to the aforementioned birds, two species were nesting in artificial habitats. A few pairs of Bank Swallows (Riparia riparia) had burrows in a small gravel pit. Tree Swallows (Iridoprocne bicolor) were nesting in cavities in an old building. Both species were observed feeding, particularly over the ponds in the marsh. One Bank Swallow was collected.

\section{TRANSIENT BIRDS}

Birds of 25 species were regarded as transients or accidental invaders of the island.

Gavia stellata. Red-throated Loon. One was seen on June 6, swimming in the largest pond.

Branta nigricans. Black Brant. Two were seen on June 11, and again on June 12. Three were present on June 14, and a single bird was seen on June 27 . All were on the largest pond. Although quite wary, the birds were observed at length through binoculars.

Aythya marila. Greater Scaup. An adult male was found dead on June 6 along the margin of the largest pond.

Histrionicus histrionicus. Harlequin Duck. An adult male was seen on June 27 a short distance off the north shore.

Melanitta perspicillata. Surf Scoter. A flock of about 20 birds was seen on June 10. It was some distance off the south end of the island. 
Mergus sp. Merganser. A female merganser, unidentified as to species, was observed on June 11.

Falco sp. Falcon. A falcon, first thought to be a Gyrfalcon, was seen perched on a rock at the south end of the island on June 5 . Its identity could not be established.

Arenaria melanocephala. Black Turnstone. On June 25, three Black Turnstones were observed along the west beach. A female, weighing 123.1 grams, was collected; the largest follicle measured $3 \mathrm{~mm}$., and a brood patch was lacking. Two more birds were seen here on June 27 .

Numenius phaeopus hudsonicus. Whimbrel. Two birds were seen along the north beach on June 11 and 13. On June 14, four were present in the same area; a male was collected. The testis measured $5 \mathrm{~mm}$, and the plumage was badly worn. On June 25 , a flock of 28 birds was observed in the same area. A female collected at this time had an enlarged oviduct.

Totanus flavipes. Lesser Yellowlegs. Single birds were seen on June 5 and 9.

Limnodromus griseus caurinus. Short-billed Dowitcher. This species was first recorded on June 25 , when a flock of eight birds was seen resting on a small hummock in the largest pond. A female was collected on June 25 ; this bird weighed 104.3 grams and had a brood patch.

Ereunetes pusillus. Semipalmated Sandpiper. Sandpipers of this species were observed on June 25, feeding with Western Sandpipers around the largest pond. A female was collected; the largest follicles measured $2 \mathrm{~mm}$. and the brood patch was refeathering.

Ereunetes mauri. Western Sandpiper. Although absent in early June, Western Sandpipers had become numerous by June 25. Several flocks were observed feeding around the margins of the ponds. Seven specimens were collected on June 25 . All were in good condition, with moderate to heavy fat. All had brood patches refeathering.

Phalaropus fulicarius. Red Phalarope. On June 26, a single Red Phalarope was seen feeding with other shorebirds at the margin of the largest pond. It was collected and was found to be a male in breeding plumage. It weighed 44.7 grams, with testis measuring $9 \times 3 \mathrm{~mm}$. Molt was beginning.

Stercorarius parasiticus. Parasitic Jaeger. A Parasitic Jaeger was seen on June 10, flying across the island at a moderate altitude. It was collected and found to be a male in melanistic plumage. The testis measured $15 \times 7 \mathrm{~mm}$.

Larus glaucescens. Glaucous-winged Gull. The status of the Glaucous-winged Gull was not determined. A few adults were observed around the south end of the island from time to time, but no nests were found. It is possible, however, that they might have nested on a rock pinnacle a short distance off shore. As many as 30 immature birds were seen at one time along the beaches, where they sometimes fed upon dead seals or other material. Three specimens in immature plumage and one adult were collected.

Synthliboramphus antiquum. Ancient Murrelet. A few of these birds were seen off shore during late June. A female was collected on June 27. It weighed 153 grams; the follicles were minute.

Asio flammeus. Short-eared Owl. A Short-eared Owl was seen flying over the higher terraces on June 9. Presumably the same bird was flushed in the marsh on June 10.

Nuttallornis borealis. Olive-sided Flycatcher. One of these flycatchers was seen on June 26, perched on the dead branch of a willow at the foot of the bluff. It was collected and found to be a male. It weighed 38.8 grams, and the testis measured $11 \times 4 \mathrm{~mm}$.

Eremophila alpestris arcticola. Horned Lark. On June 9, a Horned Lark was flushed on the highest terrace. It alighted and was collected. It was a female with follicles measuring up to $2 \mathrm{~mm}$.

Petrochelidon pyrrhonota. Cliff Swallow. A few of these birds were seen feeding over the ponds on June 12. No evidence of nesting was found. With the exception of a short distance along the northeast end, where a beach was lacking, the cliffs around the entire perimeter of the island were examined for nests.

Turdus migratorius. Robin. A single robin, not collected, was seen on June 5, in some low willows at the south end of the island.

Vireo olivaceus. Red-eyed Vireo. On June 26, a Red-eyed Vireo was seen, feeding in typical fashion in the top of a tall willow. It was collected and found to be a female weighing 21.5 grams. It was moderately fat, lacked a brood patch, and had follicles measuring up to $2 \mathrm{~mm}$.

Dendroica townsendi. Townsend's Warbler. On June 11, a male Townsend's Warbler, in breeding plumage, was observed at very close range along the base of the bluff. It could not be collected at the time, and no other was seen. 
Wilsonia pusilla pileolata. Wilson's Warbler. A single male weighing 8.2 grams was collected on June 26 . The testis measured $3 \times 1.5 \mathrm{~mm}$. The plumage was generally worn, and the black cap was very poorly defined.

\section{DISCUSSION}

The avian fauna of Middleton Island is comprised of approximately 20 breeding species, most of which occur throughout the Prince William Sound region. Conspicuously absent are those birds associated with the Sitka spruce-hemlock forest which is the major ecologic formation on the islands of the Prince William Sound archipelago and on the adjacent mainland. The species that breed in alpine habitat on the mountainous islands to the north are also lacking. It is evident that the number of species of birds breeding on Middleton Island is limited by the lack of ecological diversity. The small size of the island restricts the occurrence of some species (for instance, the Anatidae), but it appears doubtful that its relatively isolated position has much influence.

The Song Sparrow (Melospiza melodia) was unexpectedly absent from Middleton Island. This bird is widely distributed in the Prince William Sound region where, as is characteristic farther to the west, it breeds commonly in the plant communities of the seashore (especially in Elymus). It would seem that its habitat requirements are fulfilled on Middleton Island, and its absence is difficult to explain. It seems possible that a small, resident population of Song Sparrows, if restricted essentially to the beach ridge formation, might have been adversely affected by the depredations of foxes during the years in which fur farming was practiced here.

The Lapland Longspur is a bird of the tundra biome. In the approximate latitude of Middleton Island, it has not been known previously to breed east of the Alaska Peninsula. Although the flora of Middleton Island probably has been derived from the islands and mainland to the north (Thomas, 1957), the vegetation of the upper terraces has a tundra-like appearance. From the standpoint of vegetational form, Middleton Island resembles islands in the lower Alaska Peninsula-Aleutian region more than it does those of the Prince William Sound archipelago. In the case of the Lapland Longspur, the form of the vegetation may be much more important than its qualitative composition.

The cliff-nesting birds of Middleton Island showed unusual behavior in connection with their nesting. Although it was not practicable to make an accurate count, it was estimated that the kittiwakes numbered several thousands. It was evident that all available nesting sites were occupied. According to Coulson and White (1956), the older birds probably return to the nesting sites of the previous year, and they also begin to nest earlier than do the young birds. In colonies which have nearly attained the maximum size permitted by the available habitat, the younger birds are forced to utilize nest sites that are marginal. On Middleton Island, it was observed that the late-nesting kittiwakes occupied the sites near the bottom of the cliffs, many of which were only a few feet above the high tide line. When Dr. John Thomas revisited the island in August, 1956 , these nests alone contained relatively small young.

Along the top of the cliffs, the kittiwakes did not nest appreciably later than those along the upper cliff sides. The earliest hatching of young occurred in the latter situation, but there was a broad overlap between the two nesting groups. From this, it might be concluded that the level ground along the top of the cliff is relatively acceptable habitat, and it is utilized to a large extent by the older, early-nesting birds.

The nests along the cliff top were identical in construction with those on the cliff sides, and they were similarly spaced. In general, they represented an extension of the nesting colony from below. Similar nesting of kittiwakes has been reported by Paludan (1955); in this case the nests were located on boulders, piles of debris, and other material on a low, flat island. 
The nesting of the kittiwakes on level ground may not be unusual behavior despite its infrequent occurrence. Such nesting can be successful only in the absence of terrestrial predators, of which the arctic fox is foremost in importance. The breeding range of the kittiwake corresponds to the range of the arctic fox throughout the holarctic region. On islands such as St. Lawrence and St. Matthew, in the Bering Sea, the writer has observed that kittiwakes typically place their nests on ledges quite inaccessible to foxes, which have great ability to climb such cliffs in search of birds and nests (Braestrup, 1941). It is true that the cliff nesting takes precedence over ground nesting, but factors other than the simple selection of sites may be involved. It is possible that ground nesting is usually begun as a gradual process in the presence of an established cliff-nesting colony, and that the birds do not directly colonize habitats that favor ground nesting alone. The adaptation to cliff nesting in the kittiwake has been discussed by Cullen (1957).

Murres were observed in but three widely separated localities (fig. 2); there were about 400 birds in the aggregate. The largest colony, of just over 200 birds, was nesting on level ground along the top of the cliff (fig. 6). The number of eggs here indicated that about 50 pairs were nesting. The restriction of the murres to so few colonies might indicate unsuccessful competition with the kittiwakes. Such competition could be direct, but the kittiwakes appeared to be earlier nesters and probably excluded the murres by occupying most of the nesting sites. Since murres usually nest high on cliffs, they seem to be less adaptable than the gulls in the selection of nesting sites. The absence of predators in this case would appear to make ground nesting at least moderately successful. It was noted, however, that a large proportion of the eggs of murres on the cliff top was destroyed, evidently by Glaucous-winged Gulls. Long term observations would be necessary to make possible an understanding of the relationships involved between the murres and the kittiwakes.

The transient birds observed on Middleton Island fall into two categories: (1) those species of obviously casual occurrence, often recorded on the basis of a single individual, and (2) the nonbreeding shorebirds, which occurred in flocks during the last half of June. Among the latter, the Western Sandpiper and the Whimbrel were particularly conspicuous, but also present in some numbers were the Short-billed Dowitcher, the Black Turnstone, and the Semipalmated Sandpiper. The birds representing the latter group were in breeding plumage, and in some the gonads were regressing. These birds apparently had reached their breeding grounds, attained breeding condition, but had been unsuccessful in nesting. It was not possible to determine how long these birds remained on Middleton Island, but Dr. Thomas observed flocks of Whimbrels in early August, and shorebirds of smaller species were abundant. It appears that such birds may pass the earlier part of the summer in favorable habitat, such as Middleton Island, and eventually migrate with the birds which have nested successfully. Marshall (1952) studied nonbreeding in arctic birds on Jan Mayen Island, but he was concerned only with those birds which remained on the nesting grounds. There appears to be little information on the early migration of such arctic birds which have failed to nest.

Little is known of the birds found on Middleton Island during migration. In May, 1788 , it was noted that ". . geese and other species of water-fowl flock there in great numbers ..." (Coxe, 1803). The island would seem to be especially well situated in relation to migration routes across the Gulf of Alaska, and, with its tundra-like character, it might well attract arctic species which would avoid the islands to the north. The invasion of Snowy Owls during the fall of 1957 is of interest in this connection, since none was reported in the Prince William Sound region or elsewhere in the timbered 
regions of southern Alaska during this time. Middleton Island would seem to afford a location where further ornithological studies might be rewarding.

\section{ACKNOWLEDGMENTS}

The writer wishes to express his appreciation to Dr. Norman J. Wilimovsky of the United States Fish and Wildlife Service, and to Dr. John H. Thomas, of Stanford University, for the opportunity to join them in the work on Middleton Island. Lt. Col. Lucien T. Zell and Major William F. Will, United States Air Force, provided logistic and other assistance whenever possible. The support of Dr. Ira L. Wiggins, of Stanford University, and Dr. L. O. Quam, of the Office of Naval Research, is gratefully acknowledged. Dr. H. H. Ross, of the Illinois Natural History Survey Division, identified the caddisflies. Mr. Francis S. L. Williamson, of this Center, prepared some of the specimens and kindly read the manuscript. Mrs. R. V. Rausch, also of this Center, prepared the figures.

\section{SUMMARY}

A survey of the birds of Middleton Island was made by the writer in June, 1956. Forty-five species of birds were recorded. Of these, at least 16 species were breeding, four other species were possibly breeding, and 25 species were regarded as transients. The distribution of the breeding birds was correlated with six major ecological formations. Five of the latter were based on vegetational characteristics, while the rocky cliffs comprised the sixth.

The avian fauna of Middleton Island consists mainly of species found in the Prince William Sound region, to the north. An important exception was the Lapland Longspur, which previously has not been known to breed east of the Alaska Peninsula at the latitude of Middleton Island. Both murres and kittiwakes were found to be nesting on level ground along the top of the cliffs. Flocks of nonbreeding shorebirds were observed. These and other findings have been discussed.

\section{LITERATURE CITED}

American Ornithologists' Union.

1957. Check-list of North American birds. Fifth Ed. (published by the Union, Baltimore, Md.). Braestrup, F. W.

1941. A study on the arctic fox in Greenland. Immigrations, fluctuations in numbers based mainly on trading statistics. Medd. om Grønland, 131:1-101.

Coulson, J. C., and White, E.

1956. A study of colonies of the kittiwake Rissa tridactyla (L.). Ibis, 98:63-79.

Coxe, W.

1803. Account of the Russian discoveries between Asia and America. To which are added, the conquest of Siberia, and the history of the transactions and commerce between Russia

Cullen, E. and China (J. Easton, London).

1957. Adaptations in the kittiwake to cliff-nesting. Ibis, 99:275-302.

Grinnell, J.

1910. Birds of the 1908 Alexander Alaska Expedition with a note on the avifaunal relationships of the Prince William Sound district. Univ. Calif. Publ. Zool, 5:361-428.

Heller, $\mathbf{E}$

1910. Mammals of the 1908 Alexander Alaska Expedition with descriptions of the localities visited and notes on the flora of the Prince William Sound region. Univ. Calif. Publ. Zool., 5:321-360.

Marshall, A. J.

1952. Non-breeding among arctic birds. Ibis, $94: 310-333$. 
Rausch in the Condor (July 1958) 60. Copyright 1958, Cooper Ornithological Society. Used by permission.

Miller, D. J.

1953. Late cenozoic marine glacial sediments and marine terraces of Middleton Island, Alaska. Jour. Geol., 61:17-40.

Paludan, $\mathrm{K}$.

1955. Some behaviour patterns of Rissa tridactyla. Vidensk. Medd. Dansk Nat. Foren., 117:1-21. Ridgway, $\mathbf{R}$.

1893. Scientific results of explorations by the U.S. Fish Commission Steamer Albatross. No. XXVII-Catalogue of a collection of birds made in Alaska by Mr. C. H. Townsend during the cruise of the U. S. Fish Commission Steamer Albatross, in the summer and autumn of 1888. Proc. U. S. Nat. Mus., 16:663-665.

Thomas, J. H.

1957. The vascular flora of Middleton Island, Alaska. Contrib. Dudley Herbarium, 5:39-56.

Arctic Health Research Center, Public Health Service, Anchorage, Alaska, January 3,1958 . 